\title{
ÁREA III
}

MARIA DOLORES WANDERLEY

Estudo de uma Seção Cretácica da Bacia Potiguar com Base em Nanofósseis Calcários

85 
Orientador: Ignácio Brito

Resumo:

Os estratos do Cretáceo superior e parte do inferior da Bacia Potiguar podem ser individualizados nas seguintes biozonas:

Nannoconus truiti, Axopodorhabdus albianus, Stonerius achylosus,

Lithastrinus grillii, Eiffellithus exinius, Quadrum trifidium, Arkhangelskiella cymbiformis. O Cenomaniano Médio-Turoniano Inferior constitui intervalo de tempo durante o qual houve deposição de espesso pacote sedimentar na área estudada. 